\title{
11
}

\section{THE MODERN HISTORY OF IRAN AND THE BIRTH OF THE SHIA PROXY MODEL}

\author{
Alex Vatanka
}

In February 2019, the Islamist political system in Tehran turned 40 years old. In 1979, Iran's ancient monarchy was replaced by the modern world's first theocracy, led by Supreme Leader Ayatollah Ruhollah Khomeini. Unlike his predecessor, the pro-Western Mohammad Reza Pahlavi (the shah), Khomeini had only vague notions about his preferred foreign policy agenda and Iran's place in the world.

Then came the seizure of the U.S. Embassy in Tehran in November 1979 at the hands of Islamist militants. By endorsing the seizure, Ayatollah Khomeini unleashed a process that soon upended the close economic, military, and strategic ties that Iran had enjoyed with the United States since 1941. American presidents from Franklin D. Roosevelt to Jimmy Carter had viewed Iran as an anchor of American influence in the Middle East and in particular a key frontline state against the Soviet Union and the expansion of communism.

With the arrival of the Islamist regime in Tehran, the once-close relations-where at one point some 50,000 Americans lived and worked in Iran — came to an abrupt end. ${ }^{1}$ Instead, the United States has functioned as the primary ideological target of enmity for Iran's Shia Islamist leadership since 1979.

This chapter provides a short history of contemporary Iran before outlining the challenges that the Iranian Islamist regime poses from an American perspective. The evolution of Iranian foreign policy behavior is then tracked through Tehran's posturing over the last 42 years during a number of military conflicts where Iran has either been a direct participant or an influential actor. As such, it discusses the birth of the Shia proxy model and Iranian-sponsored Hezbollah. Finally, the chapter concludes by identifying key domestic drivers that shape Iranian foreign policy and what this reality signals for Tehran's future priorities on the regional and international stages.

\section{The 1979 Islamic revolution}

Reza Khan propelled himself to power after a coup against the Qajar Dynasty in 1921 fueled by popular anger in Iran about the country's general decline and vulnerability to the British and Russian colonial powers in the period immediately following World War I. He pronounced himself shah, or monarch, of Persia. With this proclamation, the Pahlavi Dynasty began. ${ }^{2}$

Reza Khan advertised modernization as his foremost approach to improving the dynasty and its welfare. In 1935, the dynasty underwent a formal name change from Persia to Iran. Public schools, modern universities, and Westernized clothing were all hallmarks of Reza Khan's guise of modernization, and with it came a swifter approach to dictatorial rule. 
Reza Khan's son and successor, Mohammad Reza Shah, succeeded to the throne in 1941. Over the next 38 years, his links to the United States would eventually drive the country to a revolution. The Central Intelligence Agency's active participation not only propelled the overthrow of the country's prime minister, Mohammad Mossadeq, in 1953, but the United States also contributed significant military aid toward the development of the Shah's secret police force-the SAVAK. ${ }^{3}$

In 1963, the shah essentially tried to force a series of Western economic and social reforms on the Iranian people, known as the White Revolution. ${ }^{4}$ Many traditionalist Iranians found comfort for their many economic, social, and political grievances in the clergy, who would soon play a large role in the overthrew of the Pahlavi regime in 1979.

By 1979, the political unrest had grown into a revolution, and the shah was ultimately forced to flee to Egypt in January. On February 1, after 14 years in exile, the Ayatollah Ruhollah Khomeini returned to lead the country. This would be known as the 1979 Iranian Revolution.

Within months after coming to power in February 1979, Ayatollah Khomeini was deliberately but inconspicuously employing the Islamic Revolutionary Guards Corps (IRGC) — the organization that he authorized and which subsequently became the regime's political-military vanguard to protect the new Islamic government from threats - to marginalize the appointed Prime Minister Mehdi Bazargan and the so-called "liberal," or moderate, current by using the IRGC as an instrument to undermine Bazargan. ${ }^{5}$ The U.S. Embassy in Tehran had initially welcomed Khomeini's appointment of Bazargan. ${ }^{6}$ Then, on November 4, 1979, a group of Khomeini-backed radicals stormed the U.S. Embassy, taking 66 Americans hostage. Khomeini supported the seizure, but Bazargan's government opposed it.

Bazargan's first split with the ayatollah, however, had appeared a number of months earlier over an issue that would prove equally far reaching. In March 1979, a nationwide referendum was held about the coming post-shah political system. ${ }^{7}$ Bazargan and his liberal faction sought to have the ballot ask if the voters wanted a "democratic Islamic republic." ${ }^{8}$ Khomeini overruled them, and the word "democratic" was dropped as the ayatollah maintained that "Islam itself was democratic." Following the March vote, Iran became an "Islamic Republic," and Khomeini and his inner circle began to formulate its characteristics and neutralized those who opposed the new constitutional arrangement.

It was an ominous sign of what would follow. It was also a prime example from the earliest days of postshah Iran about a struggle to define, own, and defend the "revolution" and "Iranian interests" by various regime personalities, factions, and institutions ever since. In the realm of foreign policy, a few concepts at first emerged as unshakable creed, including opposition to the United States, Israel, and a belief that armed struggle was the way forward. Meanwhile, Khomeini saw his revolution as borderless.

\section{0-1988: The Iran-Iraq War and the birth of the Shia proxy model}

In 1980, next door in Iraq, Sunni strongman Saddam Hussein had for months been weighing his options following Iran's revolution and Khomeini's rise to power. The new Shia Islamist revolutionary government in Tehran was determined to undermine Saddam's rule by inciting Iraq's Shia majority against him. ${ }^{10}$ Yet Baghdad did not know if the new political reality in Tehran would be a lasting one. Would the exiled shah, backed by the United States, ultimately return, as had been the case in 1953 ?

The answer to that critical question came on July 27, 1980. That was the day the shah passed away while in exile in Cairo. ${ }^{11}$ Saddam interpreted the shah's death to mean that Khomeini and his Shia Islamist revolutionaries were in power to stay, and he opted to act before they could take the fight to him.

As it turned out, Saddam's invasion of Iran on September 22, 1980, was a blessing for the radical clergy in Tehran. As with the U.S. Embassy hostage incident, it acted as a major distraction for the Iranian public and an opportunity for a further Islamist power grab. For the ordinary Iranian and almost all political strands of the time, the war became a case of country before politics or ideology. ${ }^{12}$ The notable exception 
was Khomeini's camp. They invariably came to regard the anti-Saddam war as an event to proliferate Khomeini's ideas about "Islamic Government," a concept they flaunted as universal in its mission. ${ }^{13}$

In its most exorbitant vocalization, it was a messianic narrative. Earliest slogans of the war-such as "War, War Until Victory" against Iraq-soon shifted to an open-ended agenda of promising a global revolution. "War, War until the Removal of Intrigue from the Whole World" or "The Road to Jerusalem Goes Through Karbala" became the favored alternative chants of Ayatollah Khomeini's martyrdom-hungry foot soldiers. ${ }^{15}$ It was more than just bombast.

The fanaticism pouring out of Tehran was quickly turning the Arab world, as well as most of the international community, against Iran. Those killed had become shahid, or martyrs. The militant clergy and their accomplices from the IRGC had turned the defense of the motherland into the defense of Islam. This, however, meant that the war was to be endless, given the breadth of Islamic lands and the many conflicts where Tehran could choose to implant itself. As it turned out, this is exactly what happened.

Short on military expertise but full of religious and ideological zeal, Khomeinists would drag Iran through a war that ultimately lasted eight years (1980-1988) and cost billions of dollars of damage. Meanwhile, official figures show some 190,000 Iranian military forces and tens of thousands of civilians died. ${ }^{16}$ It was also in this period that Khomeini's young Islamist followers began to seek ways to spread the message of the Iranian Revolution. The model they created would prove to have a long shelf life and remain expedient in decades to come.

Early in the war effort against Iraq, Tehran and the IRGC leadership looked to take advantage of significant numbers of Iraqi Islamist-minded Shia who were abandoning Iraq because the anti-Islamist regime of Saddam Hussein proved to be a harsh suppresser of their political aspirations. ${ }^{17}$ In Khomeini's Iran, these same Iraqi Shia Islamist dissidents were welcomed with open arms.

Iran quickly invested significant resources to indoctrinate these Iraqi Shia and in many cases armed and deployed them against the Saddam regime they had fled. ${ }^{18}$ It was to be the birth of the proxy model in Iran, which the country has relied on as a key projector of its power across a number of arenas in the Middle East. For example, the now-famous external operational branch of the IRGC - the Quds Force-was initially established with heavy reliance on Iraqi Islamist exiles who as ethnic Arabs could operate behind enemy lines inside Iraq much more freely than ethnic Iranians. ${ }^{19}$

By 1982, the IRGC formed the anti-Saddam Badr Corps from dissident Iraqi Islamists with its operational headquarters in Iran. ${ }^{20}$ Also in the early 1980s, Tehran created a new organization from Lebanese Shia dissidents: Hezbollah. ${ }^{21}$ Both Hezbollah and the Iraqi Badr Corps embraced Khomeini's doctrine of sweeping political resistance. ${ }^{22}$ It was an agenda that was not only focused on a domestic agenda or rivals but also very much anti-U.S. and anti-Israeli in its ideological disposition.

Hezbollah would engage in a number of terrorist attacks against Westerners, such as kidnappings and car bombings. One of its most prominent attacks resulted in the deaths of 241 U.S. service personnel—including 220 Marines-from a truck bomb at a Marine compound in Beirut, Lebanon. ${ }^{23}$

Some four decades later, Hezbollah has become a state-within-a-state in Lebanon, while Badr is one of the most influential political actors in Baghdad. Badr's present-day leader, Hadi al-Amiri, was an early recruit by the Iranians, and his star has risen ever since, as he has enjoyed Iranian patronage. ${ }^{24}$ Following the Iraqi elections in 2018, al-Amiri was even in contention to become Iraqi prime minister as head of the renamed Badr Organization. ${ }^{25}$

In the case of Hezbollah, its leader Hassan Nasrallah does not seek to downplay his ideological dependency on the Iranian Islamist regime. As he has repeatedly said, Nasrallah considers himself a follower and a servant of Iran's Supreme Leader Ayatollah Ali Khamenei. ${ }^{26}$

Both Hezbollah and Iraq's Badr Organization remain to this day the most successful Shia militant proxies aligned with Tehran. Meanwhile, throughout the 1980s, Iranian-inspired political radicalism and acts of violence were not limited only to the Iraqi or Lebanese theaters. Acts of political violence at the hands 
of groups that looked to Iran for ideological guidance were also witnessed in Bahrain, Kuwait, Pakistan, and Saudi Arabia. ${ }^{27}$

Still, not everyone in Tehran in the 1980s believed the role of championing the array of Arab militants was the best way to promote Iranian national interests. This was most notably the case with the powerful speaker of the Iranian parliament, Ayatollah Akbar Hashemi Rafsanjani, who was sensitive to the damage such sponsorship might impose on Iran's standing as a "normal" country. ${ }^{28}$

The advances the Islamists in Tehran made on this front during the 1980s is what Iranian hardliners to this day view as highly valuable in the geopolitical struggle, where a number of Middle Eastern states engage in proxy conflict to extend their regional power in countries such as post-Saddam Iraq and later in Syria. Nonetheless, by the time of Khomeini's death in 1989, the intra-regime debate in Tehran about the utility of the export of the Islamic revolution via the proxy model ended the more excessive Iranian behaviors that had been evident in the early part of that decade.

\section{The few opportunities of the 1990s}

In comparison to the 1980s, which Iran's present-day Supreme Leader Ayatollah Ali Khamenei touted as the "golden revolutionary age," the 1990s witnessed retrenchment in Tehran's use of the proxy model. ${ }^{29}$ There were two principal factors that resulted in Iran cutting back its use of Arab Islamist proxies.

First, the key lesson learned by the moderates inside the Iranian regime was that dabbling in revolutionary rhetoric and action — such as sponsoring non-state militant actors-is inherently damaging to Tehran's reputation as a political and economic partner. This was based on Iran's experience in the Iran-Iraq war. Moderates argued that Iran should return to the international mainstream by moving away from some of the most reckless expressions of the regime's revolutionary agenda. ${ }^{30}$

Second, for most of the 1990s, there were few opportunities for Tehran to deploy its proxy model. The war with Iraq had ended in 1988. This left Iran with a handful of theaters where it could advance its foreign policy by relying on foreign militant proxies. One major exception was Iran's role in the wars that followed the breakup of Yugoslavia in 1992. The Iranians, along with Arabs and the Turks, were quick to send arms, funds, and volunteers to aid the Muslim Bosnians against their Croat and Serb adversaries. ${ }^{31}$ The Quds Force spearheaded Iran's armed operations in the Balkans in the 1990s, and it was here that, for the first time, they came to operate alongside Sunni jihadi groups, including the forerunners to al-Qaida. ${ }^{32}$

In the 1990s, the most obvious theater for Iran to operate was next door in Afghanistan. In a struggle that Tehran considered of strategic importance against the Saudi- and Pakistani-backed Sunni radicals of the Taliban, the Iranians put enormous effort into supporting the Afghan anti-Taliban forces. The Iranians directed most of this support to the Northern Alliance led by Ahmad Shah Massoud until his death in $2001 .{ }^{33}$ Unlike its use of an Islamist and often-sectarian message to mobilize Iraqi Shia recruits, Tehran kept its options open in Afghanistan, pursuing both an activist policy but also a pragmatic one that was only sometimes Islamist or sectarian.

Tehran wanted to carve out the western Afghan provinces on its border as part of its unquestionable "zone of influence" and to link Afghanistan to the Iranian sphere of economic power through pan-regional initiatives. ${ }^{34}$ Above all, the Iranians sought to avoid an Afghan central government under the thumb of the Pakistanis or the Sunni Arab Gulf states, such as Saudi Arabia. ${ }^{35}$ The Iranians opted to expand both hard and soft power in Afghanistan and did not let political affinity be the only litmus test after which Afghan groups could receive arms, financial aid, and political support.

In terms of grassroots support, the bulk of Iran's assistance went to the ethnic Shia Hazara Afghans, ${ }^{36}$ but the fact that ethnic Tajik are mostly Sunni did not stop Iran from sponsoring many of the political leaders from this community, including prominent figures such as Abdullah Abdullah, the future chief executive in the Ashraf Ghani government in Kabul. ${ }^{37}$ 
This reality did not end criticism among Afghans then or now. A common complaint from Afghan secular-leaning officials is that Tehran has essentially squandered many opportunities to constructively attract ordinary Afghans by failing to appeal to the common cultural values shared between the populations of the two countries as historic members of the Iran Zamin (Land of Iran). ${ }^{38}$

Some secular-leaning Afghan leaders instead view the Islamic Republic as either overly selective in its approach by focusing on just the Afghan Shia or the ethnic Tajiks or opting to use controversial ideological or sectarian (and often anti-U.S.) messaging that is aimed at only a minority of Afghans while making the majority anxious about ultimate Iranian intentions. ${ }^{39}$ Such fears in Kabul multiplied following the outbreak of the Syrian civil war in 2011 and after Iran began to recruit Afghan Shia to join its military campaign in support of the beleaguered Syrian President Bashar al-Assad. ${ }^{40}$

Some observers have argued that while sectarian factors play a role in Iran's strategic calculations, it is not in the single-minded, all-encompassing way that Iran's critics suggest. According to this line of thinking, the Islamic Republic, as enshrined in its constitution from 1979, ideologically committed itself to a mission of mobilizing so-called downtrodden Muslims against what Tehran labeled unjust rulers. This refers to Muslims in general and did not distinguish between Shia and Sunni. ${ }^{41}$

Nevertheless, some aspects of the Iranian political model are strikingly sectarian. For example, it is enshrined in the constitution of the Islamic Republic that only a Shia Muslim can hold the office of supreme leader and the presidency in Iran, a rigid stipulation that Iran's Sunni minority-about 10\% of the country's population - find discriminatory. ${ }^{42}$ This does not mean Iran is an outlier in this regard. Similar sectarian policies are evident across the region where Sunni-majority states exclude minority Shia from political equality. ${ }^{43}$ The central point is to underscore that Iran, too, has its own sectarian biases and is sensitive to them.

\section{The impacts of the Iraq and Syria conflicts and the Arab Spring}

If the 1990s presented few opportunities for Iran to expand its Shia proxy model of the 1980s, the U.S.-led military invasion of Iraq in 2003 and the outbreak of the Arab Spring from 2011 onwards created a number of opportune security vacuums. Accordingly, in a number of cases such as Iraq and later in Syria, Tehran looked to protect and expand its interests through the use of proxy forces under its general leadership.

Once the United States invaded Saddam's Iraq in March 2003, which led to the political rise of the Iraqi Shia, Iran stood among the top beneficiaries of the political transformation in that country. Many of Tehran's close Iraqi Islamist allies_-groups and individuals that the Iranians had sponsored since the early 1980 s - were suddenly at the heart of Iraqi power politics. ${ }^{44}$ By the time Iraq was engulfed in a sectarian conflict between the Shia majority and the Sunni minority, Iran was ready to play the role of a facilitator for many of the Shia Iraqi groups.

Put simply, the security vacuum in Iraq since 2003 paved the way for Tehran to expand its reach by either further increasing its assistance to its existing Iraqi allies or in some cases forming new militant groups that could act as Iranian surrogates. It is in this timeframe that a number of new militant Shia entities emerged on the Iraqi scene, including Asaib Ahl al-Haq (League of Righteous People) and Kataib Imam Ali (Imam Ali Brigades). ${ }^{45}$ These Shia Islamist militant groups were invariably close to Tehran and the IRGC in particular. In fact, in a couple of cases, Iraqi militants would openly declare their primary allegiance to Iran's supreme leader, Ayatollah Ali Khamenei. The most notable case was that of Saraya alKhorasani (Khorasani Brigades). ${ }^{46}$

Still, such expressions of fealty were the exceptions. Tehran's interest was not to "Iranize" the Iraqi militants that operated under its tutelage; it wanted above all to exercise ideological mentoring over these recruits who overwhelmingly came from humble social backgrounds and were looking for a political tent to call home. 
Moreover, from the U.S. perspective, one reality was undeniable: the long list of Iraqi militant groups with ties to Iran would also end up in direct conflict with U.S. forces in Iraq. This resulted in many American casualties as the IRGC aided its Iraqi minions in conducting asymmetric warfare through the use of more sophisticated improvised explosive devices and other tactics. ${ }^{47}$

Only a few years later, the eruption of a number of Arab Spring popular uprisings in 2011-from Yemen to Syria to Tunisia - and the subsequent emergence of the Islamic State became yet another reason for Tehran to stay devoted to the use of non-state militant actors. They considered it the best way to defend Iranian interests outside of the country's borders. This campaign was relatively inexpensive compared to a full-out conventional military response. In comparison, for example, the Saudi and Emirati military interventions in Yemen since 2015 have by all accounts cost far more in monetary terms for those intervening countries.

In terms of justifying such policies in an ideological framework, the Iranian hardliners intellectually traveled back to the zealous revolutionary days of the 1980s and came up with the concept of "Axis of Resistance." ${ }^{48}$ It is essentially a catchall phrase that can be cited by Tehran as a way of justifying a range of actions. This includes the constant ideological enmity toward the United States and its regional alliesnamely Israel and the Gulf Sunni Arab states - to rationalize the formation of non-Iranian, non-state militant entities that act as Tehran's collaborators. ${ }^{49}$

As had been the case in Afghanistan and in Yugoslavia in the 1990s, Tehran would not let sectarian realities prevent it from pursuing its strategic goals. In Syria, the Iranian mobilization in the defense of the Bashar al-Assad regime was presented not as a Shia cause - since the regime of al-Assad is and has always been a secular entity-but as an effort against what Tehran called an American and Israeli plot to weaken the hand of those states and groups in the "Axis of Resistance" that oppose American hegemony in the Middle East. ${ }^{50}$

From the outside, it might seem to be the case of local actors (in places such as Iraq or Syria or among the Palestinians) looking for foreign patronage and hence a client-patron relationship. The association is less than a marriage of convenience and more the case of a mothership (Iran) on a distinct ideological trajectory; its goal is to cause fellow travelers (proxy groups) to come with it on the ride, even though the final destination is less than clear even for many in Tehran.

In fact, there has been far more clarity and consistency in terms of Tehran's modus operandi in operationalizing the militant proxies that have come under its wings. With the experiences of the early 1980s still relatively fresh - when Tehran was instrumental in founding Hezbollah and Iraqi Badr-the generals from the IRGC only had to return to the past blueprint to expand the proxy model that they were about to help spread in the Middle East.

The rewards for such a policy have been readily measurable. According to Nick Heras, 40 out of the estimated 67 Popular Mobilization Forces militias in Iraq in 2018 shared close links with the IRGC. ${ }^{11}$ By the end of 2017, an estimated 50,000 fighters from Popular Mobilization Forces mobilized against the Islamic State were in units under direct or indirect Iranian control. ${ }^{52}$

To put this number in perspective, the total number of fighters from Popular Mobilization Forces was at the time estimated at $110,000-122,000 .{ }^{53}$ The hardline generals from the IRGC pointed to this fact as an Iranian strategic success. ${ }^{54}$ From their vantage point, the use of non-Iranian proxies provided Tehran with strategic depth at a low cost. Not everyone in Tehran viewed it the same way.

\section{The fight over foreign policy in Iran}

Since 2011, the IRGC has pushed to maintain and expand its militant proxy model as an inherent instrument of power projection in the region. As a country, however, Iran's political, diplomatic, and economic needs and interests go far beyond the mere question of carving out and nurturing ostensible strategic depth in a handful of Arab states via the proxy model vehicle. 
There is another way of looking at this Iranian predicament. Put simply, Iran's recent successes on the battlefields in Iraq and Syria have translated into some political capital but only at a steep cost. It is not clear whether these victories are permanent or reversible. For example, as the al-Assad regime moved toward total military victory against the Syrian opposition by 2018 , the Iranians suddenly found themselves wondering if they could remain a dominant actor in the post-war future of Syria.

Most importantly, the Russians-Iran's principal tactical collaborators in Syria on the side of al-Assad since September 2015- began to show signs of wanting to part ways with Tehran. ${ }^{55}$ At a minimum, Tehran felt the Russians were working hard to minimize Iran's future role in post-war Syria, an outcome that Moscow could only seek because of general Iranian estrangement from other key actors-principally the United States and the Arab states of the Persian Gulf-who have a voice in the long-term normalization of Syria.

In other words, thanks to Iran's weak international diplomatic hand, its otherwise significant military victories on the battlefield via the militant proxies it controls in Syria quickly showed themselves to be hardly a guarantee of long-term broader strategic successes as the generals from the IRGC claimed. Iran's proxy model delivered results during the stages of military conflict, but it struggled to convert battlefield wins into firm political victories.

Internal critics of the militant proxy model in Iran's foreign policy have instead argued it is an unsustainable way to project Iranian power. It might have been relatively inexpensive as compared to other military campaigns occurring at the same time in the region, but the indirect costs and consequences were considerable and potentially lethal to the staying power of the Islamic Republic's grip on power in the region. ${ }^{56}$

In terms of domestic political ramifications, it was abundantly clear that many Iranians viewed the military interventions in Iraq and in Syria as ideologically driven wars of choice that were not critical to Iranian national security. In a number of nationwide socio-economic protests that Iran experienced in 2017 and 2018, the top slogans of the demonstrators were aimed at Tehran prioritizing foreign ideological pursuits over the everyday needs of the Iranian population. ${ }^{57}$ Such incidents highlighted the gap between the ruling elite in Tehran - particularly the hardline elements - and the Iranian public. This is the sort of grievance that if left unaddressed could fundamentally put the political future of the Islamic Republic in question.

The May 2018 decision by the Trump administration to abandon the 2015 nuclear deal and reimpose sanctions also provided further debate in Tehran, since its controversial and costly regional policies are explicitly responsible for U.S.-led international isolation. ${ }^{58}$ That being said, while the Trump administration's pursuit of a "maximum pressure" campaign damaged Iran economically through sanctions, it did little to counter Tehran's most objectionable policies: the expansion of Iranian hard power via its control of political and militant groups aligned with the Islamic Republic.

A year after the assassination of Quds Force leader Qassem Soleimani in January 2020, which was arguably the most lethal step the U.S. military has taken against Iran's Shia proxy model, Tehran's regional footprint had not diminished. ${ }^{59}$ Iran was still pursuing its policy aims in Lebanon, Syria, and Iraq. In October 2020, after a five-year absence, Iran even sent an ambassador back to war-stricken Yemen, a country where Iran has backed the Houthi rebels against the U.S.-backed Saudi and Emirati forces. In other words, while putting sanctions on Iran cost the United States relatively little, pushing back against Iranian efforts militarily in the region will require far more U.S. commitment and investment.

\section{Iran's choice: to be a "normal" or "revolutionary" state?}

When Iranian President Hassan Rouhani was elected in 2013 and re-elected in 2017, many in the West hoped it might be a moment of Iranian introspection. Tehran, it was thought, might not stop only at compromising over its nuclear program but extend its concessions to include its future relationship with Islamist militant groups that it had sponsored in one way or another since 1979. That was not to be. The hardliners 
in the Iranian regime, not least Supreme Leader Ayatollah Ali Khamenei and the IRGC generals, remained deeply suspicious of Western intentions, and especially of the United States and Israel.

The rise of the Islamic State in Syria and then in Iraq from early 2014 militarized Tehran's response to the vehemently anti-Iranian group. The IRGC was, by default, Tehran's first line of defense. The March 2015 Saudi intervention in Yemen in the name of fending off an Iranian presence in southern Arabia further exacerbated the zero-sum game of regional rivalry between Iran and Saudi Arabia. The IRGC's stated objective of preserving the al-Assad regime in Damascus while neutralizing the Islamic State in Iraq faced no genuine pushback from the Rouhani government.

The arrival of the presidency of Donald Trump also put the brakes on efforts to reduce IRGC powers. Supreme Leader Ali Khamenei, who sets the fundamental course in Iranian foreign policy, chose not to give in to American pressure in regard to Tehran's regional interventions. This meant that the Iranians doubled down on their investments in places such as Iraq and Syria. For the IRGC, it was again convenient and imperative to stress the value of the cherished militant proxy model and point to the depth it gives Iran in various theaters in the Middle East as a deterring factor in a potential American decision to attack Iran militarily.

Nor does Khamenei believe more concessions will satisfy Washington's demands. He has repeatedly stated that compromising with the United States will not be possible, as Washington's basic strategic goal is to bring about regime change in Tehran. ${ }^{60}$ To deter the United States from seeking this objective, Khamenei and his hardline supporters believe the Islamic Republic should remain "revolutionary" and double down on efforts to spread its message both ideologically and operationally. Iran's continued support for foreign militant proxies, and particularly those from the Arab countries, has to be viewed in this context.

\section{Conclusion}

Iran, a country of 82 million people and a considerable amount of political competition within the ranks of the Islamist ruling elite, will continue to be a critical policy challenge for the United States. There is no doubt that the two principal factions in the Islamic Republic - the so-called "pragmatists" and the "hardliners" - have differences of opinion in regard to Iran's foreign policy agenda. The trajectory of this foreign policy competition will be greatly shaped by a number of factors, including the outcome of the succession process already underway to replace Supreme Leader Ayatollah Ali Khamenei and American policy toward Tehran in the next few years.

The "pragmatists" insist that Tehran should and can seek some kind of accommodation with the United States, which will prevent Iran from becoming internationally isolated or entirely beholden to Russia or China for its diplomatic or trade needs. In opposition, the "hardliners" believe that an accommodation with the United States is not only impossible but unadvisable, since this faction believes Washington's bottom-line objective is to bring about the end of the Islamic Republic.

In the midst of this policy competition, the "hardliners" have emerged as the undisputed handler of Iran's foreign policy agenda. Iran's Arab policy is seemingly overwhelmingly shaped and implemented by the IRGC.

The IRGC's overall success, however, is still far from universally accepted in Iran. Not only is it a deep source of resentment for the Iranian public, but the IRGC's modus operandi for the Arab world is even questioned at the most senior ranks within the regime. As described in this chapter, Iran's "forward defense" has evolved and is a relatively nimble concept in its application as long as it can advance Tehran's regional agenda. In a nutshell, the pitch has been as simple as the argument that Iran is better confronting its Arab rivals and the Americans outside of Iran's borders than inside them.

Hence, the strategists behind this Iranian approach to the Arab world and Tehran's geographic vicinity in general have tended to defend "forward defense" as not only protecting Iran from possible foreign invaders but as a vanguard against Western and secular political influences in the broader Middle East. 
Tehran's Arab strategy from 2003 highlights two basic realities. First, Iran has demonstrated agility in defining and implementing security policy in the region. Second, Iran's activities in the Arab world reveal a consensus among Iranian policymakers that the appetite of the Iranian public for "forward defense" is finite. On the other hand, Tehran's mobilization of non-Iranian forces has been a double-edged sword. It helped resolve Iran's manpower problems, but in strengthening appeals to transnational ideological claims, Iran provided its regional rivals with a convincing argument that Tehran was indoctrinating, funding, and arming a new generation of Shia militants and fueling a regional Shia-Sunni sectarian divide.

Iran, a non-Arab and Shia majority country with aspirations to lead the Islamic world, has always been highly sensitive to the charge of acting as a Shia sectarian power, and it has invested heavily in countering this criticism. Nevertheless, the priority of keeping al-Assad in power superseded Tehran's wish to maintain its credibility in the eyes of the Sunni street. As a result, Iran's approach helped mobilize opposition to Iranian policy and stoked fears that Iran was seeking more revisionist aims.

It is far from clear whether Iran can sustainably pursue this strategy. Iranian society is showing unmistakable signs of concern regarding the limits of forward defense and all the direct and indirect costs associated with it. Iran's rivals appear to have assessed that those strains are sufficient and that Iran will fold when confronted. What is clear, however, is that this uncertainty brings with it the risk of repeated crises with the potential for escalation.

\section{Notes}

1 Suzanne Maloney, “1979: Iran and America," Brookings, January 24, 2019, www.brookings.edu/opinions/ 1979-iran-and-america/.

2 Michael P. Zirinsky, "Imperial Power and Dictatorship: Britain and the Rise of Reza Shah, 1921-1926," International Journal of Middle East Studies 24, no. 4 (1992): 639-663.

3 John P. Miglietta, American Alliance Policy in the Middle East, 1945-1992: Iran, Israel, and Saudi Arabia (Lanham, MD: Lexington Books, 2002); Bethany Allen-Ebrahimian, "64 Years Later, Central Intelligence Agency Finally Releases Details of Iranian Coup," Foreign Policy, June 20, 2017; Nasser Karimi and Jon Gambrell, “Torture Still Scars Iranians 40 Years After Revolution," Associated Press, February 6, 2019, https://apnews.com/article/072580b 5f24b4f8ea2402221d530257e.

4 Maloney, "1979: Iran and America."

5 Ali Alfoneh, Iran Unveiled: How the Revolutionary Guards Is Turning Theocracy Into Military Dictatorship (Washington, DC: American Enterprise Institute, 2013).

6 Kenneth M. Pollack, The Persian Puzzle: The Conflict Between Iran and America (New York: Random House, 2005). Others, too, had welcomed the appointment, including Iran's Arab neighbors to the south. For more on this, see F. Gregory Gause III, The International Relations of the Persian Gulf (New York: Cambridge University Press, 2009).

7 Ronald Koven, "Khomeini Decrees Islamic Republic After Vote in Iran," Washington Post, April 2, 1979 , www. washingtonpost.com/archive/politics/1979/04/02/khomeini-decrees-islamic-republic-after-vote-in-iran/ c4d11a54-8981-4b91-8ca0-7d9771a8cf2c/.

8 Muhammad Sahimi, “The Ten Days That Changed Iran,” PBS Frontline, February 3, 2010, www.pbs.org/wgbh/ pages/frontline/tehranbureau/2010/02/fajr-10-days-that-changed-iran.html.

9 Ervand Abrahamian, A History of Modern Iran (New York: Cambridge University Press, 2008).

10 Bruce Riedel, “What Iran's Revolution Meant for Iraq,” Brookings, January 24, 2019, www.brookings.edu/blog/ order-from-chaos/2019/01/24/what-irans-revolution-meant-for-iraq/; Lyse Doucet, "Legacy of Iran-Iraq War Lives On,” BBC, October 5, 2015, www.bbc.com/news/world-middle-east-34444337.

11 Benedicte Rey, "Forty Years Ago, the Shah of Iran Died in Exile," Agence France-Presse, July 25, 2020, www.barrons. com/news/forty-years-ago-the-shah-of-iran-died-in-exile-01595683205.

12 Ali Ansari, “Iranian Nationalism Rediscovered," Middle East Institute, January 29, 2009, http://education.mei.edu/ content/iranian-nationalism-rediscovered.

13 Ayatollah Khomeini, "New Year's Speech: We Shall Confront the World With Our Ideology," Middle East Research and Information Project, March 21, 1980.

14 "Khomeini Rebuffs Iraq and Urges War Until 'Victory'," New York Times, January 29, 1981, www.nytimes. com/1981/01/29/world/khomeini-rebuffs-iraq-and-urges-war-until-victory.html. 
15 Behrouz Alikhani, "Popular War Songs and Slogans in the Persian Language During the Iran-Iraq War," Cambio. Rivista Sulle Trasformazioni Sociali 3, no. 6 (2013): 211-217.

16 The number of dead is still contested, although this figure is generally accepted.

17 Samir F. Ghattas, "President Saddam Hussein, Locked in a 7-Year-Old War With Neighboring Iran," Associated Press, September 30, 1987, https://apnews.com/article/ff8a42896ec185f3fdade03321e02e36.

18 Ibid.

19 Morad Veisi, "A Look at Three Decades of Iran's Secretive Quds Force," RFE/RL, January 8, 2020, www.rferl. org/a/iran-quds-force-soleimani-explainer/30366930.html.

20 Borzou Daragahi, "Badr Brigade: Among Most Consequential Outcomes of the Iran-Iraq War," Atlantic Council, August 16, 2018, www.atlanticcouncil.org/blogs/iransource/badr-brigade-among-most-consequential-outcomesof-the-iran-iraq-war-2/.

21 "Nasrallah Says Khamenei Heavily Involved in Establishment of Lebanon's Hezbollah," al-Arabiya, October 1, 2019, https://english.alarabiya.net/en/News/middle-east/2019/10/01/Nasrallah-says-Khamenei-heavily-involvedin-establishment-of-Lebanon-s-Hezbollah.

22 Matthew Levitt, Hezbollah The Global Footprint of Lebanon's Party of God (Washington, DC: Georgetown University Press, 2015).

23 Radhika Chalasani, "A Look Back at the Deadly 1983 Marine Barracks Bombing in Beirut," ABC News, October 23, 2017, https://abcnews.go.com/International/back-deadly-1983-marine-barracks-bombing-beirut/story? id $=50663026$.

24 Maher Chmaytelli, "Iranian-Backed Shi'ite Militia Chief Aims to Lead Iraq," Reuters, May 8, 2018, www.reuters. $\mathrm{com} /$ article/us-iraq-election-amiri/iranian-backed-shiite-militia-chief-aims-to-lead-iraq-idUSKBN1I91NL.

25 "Iraq Shi'ite Paramilitary Leader al-Amiri Withdraws Candidacy for PM," Reuters, September 18, 2018, www. reuters.com/article/iraq-politics-amiri/iraqi-shiite-paramilitary-leader-hadi-al-amiri-withdraws-candidacy-forpm-idUSL2N1W4067.

26 "Hezbollah Leader Reaffirms Loyalty to Iran, Khamenei," al-Arabiya, September 10, 2019, https://english.alarabiya.net/en/News/middle-east/2019/09/10/Hezbollah-leader-reaffirms-loyalty-to-Iran-Khamenei.

27 Daniel L. Byman, "How Terrorism Helps—And Hurts-Iran," Brookings, January 6, 2020, www.brookings.edu/ blog/order-from-chaos/2020/01/06/how-terrorism-helps-and-hurts-iran/.

28 In 1985, Rafsanjani was critical of the hijacking of the TWA Flight 847 by Hezbollah and wanted to work with President George H.W. Bush to release hostages from Kuwait Airways Flight 422 in 1988. See David Crist, The Twilight War (London: Penguin Books, 2012); Alan Cowell, "Ayatollah Ali Akbar Hashemi Rafsanjani, Ex-President of Iran, Dies at 82," New York Times, January 8, 2017, https://cn.nytimes.com/world/20170109/ ayatollah-rafsanjani-dead/en-us/.

29 For more details, see Alex Vatanka, Iran's Use of Shi ${ }^{i}$ Militant Proxies (Washington, DC: Middle East Institute, 2018).

30 For a discussion, see Behbod Negahban, "Who Makes Iran's Foreign Policy? The Revolutionary Guard and Factional Politics in the Formulation of Iranian Foreign Policy," Yale Journal of International Affairs 12 (2017): 33-48. See also Farhad Rezaei, Iran's Foreign Policy After the Nuclear Agreement: Politics of Normalizers and Traditionalists (New York: Palgrave Macmillan, 2018).

31 Michael R. Gordon, "Iran Said to Send Arms to Bosnians," New York Times, September 10, 1992, www.nytimes. com/1992/09/10/world/iran-said-to-send-arms-to-bosnians.html.

32 Golnaz Esfandiari, "Iranian Media Confirm Quds Force Involvement in Foreign Conflicts," RFE/RL, January 30, 2020, www.rferl.org/a/iranian-media-confirm-quds-force-involvement-in-foreign-conflicts/30408664.html.

33 Vinay Kaura, "Iran's Influence in Afghanistan," Middle East Institute, June 23, 2020, www.mei.edu/publications/ irans-influence-afghanistan.

34 Sajjan M. Gohel, “Iran's Ambiguous Role in Afghanistan," CTC Sentinel 3, no. 3 (2010): 13-16; Saurav Sarkar, “Iran's Afghanistan Balancing Act," Stimson Center, July 27, 2020, www.stimson.org/2020/irans-afghanistan-balancing-act/.

35 Mohsen M. Milani, "Iran’s Policy Towards Afghanistan,” Middle East Journal 60, no. 2 (2006): 235-256.

36 Ibid.

37 Obaidullah Obaid, "How Iran's New Quds Force Commander Could Hurt the US in Afghanistan," Atlantic Council, March 11, 2020, www.atlanticcouncil.org/blogs/iransource/how-irans-new-quds-force-commander-couldhurt-the-us-in-afghanistan/.

38 Davood Moradian, the chief of Presidential Programs for President Hamid Karzai, interview with author, Kabul, Afghanistan.

39 Ibid.

40 Kathy Gannon, "Iran Recruits Afghan and Pakistani Shiites to Fight in Syria," Associated Press, September 16, 2017, https://apnews.com/article/4731b95dae684f77b27d83c26e72a276. 


\section{Alex Vatanka}

41 “Iran (Islamic Republic of)'s Constitution of 1979 with Amendments Through 1989," Comparative Constitutions Project, PDF generated February 4, 2020.

42 Central Intelligence Agency, “World Factbook: Iran,” World Factbook, accessed September 16, 2020, www.cia.gov/ library/publications/the-world-factbook/geos/ir.html.

43 For a comprehensive overview, see "Sectarianism in the Middle East and Asia," Middle East Institute, November 1, 2019, www.mei.edu/publications/sectarianism-middle-east-and-asia.

44 Vatanka, Iran's Use of Shi i Militant Proxies.

45 Ibid.

46 Nafiseh Kohnavard, “Tikrit: Iran Key in Fight to Wrest City From IS,” BBC, March 3, 2015, www.bbc.com/news/ world-middle-east-31705600.

47 Office of the Spokesperson, "Department Press Briefing-April 2, 2019," U.S. Department of State, April 2, 2019, www.state.gov/briefings/department-press-briefing-april-2-2019/.

48 Robin Wright, “Iran Entrenches Its 'Axis of Resistance' Across the Middle East,” New Yorker, September 20, 2019, www.newyorker.com/news/our-columnists/iran-entrenches-its-axis-of-resistance-across-the-middle-east.

49 Ibid.

50 Ibid.

51 Nicholas A. Heras, Iraq's Fifth Column: Iran's Proxy Network (Washington, DC: Middle East Institute, 2017).

52 Ibid.

53 Ibid.

54 For a discussion, see "Reasons Behind the Successes of Iran's Regional Policies," Mashregh News, December 11, 2019.

55 Sirwan Kajjo, “Tensions Grow Between Russia, Iran in Syria,” Voice of America, May 27, 2019, www.voanews.com/ extremism-watch/tensions-grow-between-russia-iran-syria.

56 In its defense, strategists from the Revolutionary Guards constantly have to defend the model from critics. See, for example, "Iran's Defense Doctrine has Changed From 'Mere Defense' to 'Increasing the Threat to the Enemy', Tasnim News, October 1, 2016.

57 “Iranian Deputy Minister Outlines Reconstruction Projects Funded by Tehran in Syria," Radio Farda, October 6, 2020, https://en.radiofarda.com/a/iranian-deputy-minister-outlines-reconstruction-projects-funded-by-tehran-insyria-/30878768.html.

58 Mark Landler, “Trump Abandons Iran Nuclear Deal He Long Scorned,” New York Times, May 8, 2018 , www. nytimes.com/2018/05/08/world/middleeast/trump-iran-nuclear-deal.html.

59 Michael Crowley, Falih Hassan, and Eric Schmitt, "U.S. Strike in Iraq Kills Qassim Suleimani, Commander of Iranian Forces," New York Times, January 2, 2020, www.nytimes.com/2020/01/02/world/middleeast/qassemsoleimani-iraq-iran-attack.html.

60 "The Leader of the Revolution: We Will Not Negotiate with the Americans," Khabar Online, July $31,2020$. 